\title{
State Succession in International Transboundary Water Obligations: South Sudan and the Nile Water Agreements
}

\section{Abstract}

Abiy Chelkeba Worku*

South Sudan's independence has raised the number of Nile riparian states to eleven, and the questions of state succession and international law discourse on the issue are expected to arise in relation to South Sudan. Some of the international legal issues that may be raised in relation to Nile agreements are: whether the new state of South Sudan (in its utilization of the Nile waters) is under an international legal obligation to respect and honor the 1929 and 1959 Nile agreements made by Sudan with Egypt. The article addresses this issue in light of the law of state succession to treaties. Based on several theories of international law relating to state succession with respect to treaties, I argue that South Sudan is not bound by the 1929 and 1959 Nile waters agreements. More specifically, it is argued that the 1929 and 1959 agreements between Egypt and Sudan governing trans-boundary water resources do not fall within the boundary exceptional clause, and South Sudan can nullify the agreements at any time.

\section{Key terms}

South Sudan; State Succession; 1929 and 1959 Nile Water Agreements; International Water Transboundary Obligations; International Water Law

DOI http://dx.doi.org/10.4314/mlr.v10i1.4

\section{Introduction}

The people of South Sudan have struggled for more than five decades against all post independence governments in Sudan. ${ }^{1}$ More importantly, in 2005, a comprehensive peace agreement ${ }^{2}$ was signed that gave the right to secession of

\footnotetext{
* Abiy Chelkeba Worku, LL.B (MU), M.A (MU), LL.M (AAU). Lecturer of Law, Postgraduate Programs Coordinator, School of Law, Mekele University. This article has used part of the author's concept note titled "Succession of Southern Sudan to the 1929 and 1959 Nile Water Agreements and its Implication" that was written in March 2011.

${ }^{1}$ Samuel Assefa (2009), Post Referendum Prospects and Challenges the case of Southern Sudan, a paper presented on a panel discussion organized by inter-African Group, Addis Ababa, Ethiopia, 2009, p.8.

2 The Comprehensive Peace Agreement (CPA) between Sudan and South Sudan did not include an agreement on South Sudan's rights to the Nile after independence even though both parties rely on the Nile as their principal water source. At the time or writing this
} 
South Sudan by referendum, which was conducted on January 2011 . $^{3}$ This led to the birth of the youngest African state. ${ }^{4}$ As South Sudan seceded from Sudan, it has become the 11th riparian state ${ }^{5}$ of the Nile Basin. ${ }^{6}$ It is located downstream of the Nile Equatorial Lakes region and has strong connections to the Eastern Nile. ${ }^{7}$ With the emergence of South Sudan, international law issues ${ }^{8}$ are bound to arise ${ }^{9}$ and the question of state succession is expected to ensue. The author believes that greater attention will be paid to the impact of the birth of South Sudan that will have a potential impact on the Nile legal regime. ${ }^{10}$

The scope of the article does not allow detailed analysis of issues on state succession situations, including the political factor which could lead the different states to different political decisions regarding the Nile water agreement. It is sufficient for our purposes to limit the scope of the study to the legal state succession scenarios of South Sudan to the 1929 and 1959 Nile water Agreements. It is to be noted that the issue of state succession and the political development of South Sudan are very dynamic and it is often influenced by nonlegal issues. As result, this article cannot claim to be exhaustive.

Various studies have been made on state succession and majority of them focus on impact of succession in the former Soviet bloc, impact of decolonization in the new states of Africa after decolonization and its impact on territorial obligation, debt liabilities, state responsibility and the like. However,

article, South Sudan has neither signed nor entered into any agreement, whether pre-or post- independence, concerning its use of Nile.

${ }^{3}$ See, South Sudan's Flag Raised at Independence Ceremony, BBC NEWS (July, 2011), $<$ http:// www.bbc.co.uk/news/world.africa.14092375>

${ }^{4}$ Ibid.

5 Riparian means " of, relating to, or located on the banks of a river or a stream." Blacks Law Dictionary 1141 ( $9^{\text {th }}$ ed. 2009). A Riparian right is "the right of a landowner whose property borders on a body of watercourse". Id., at 1441.

${ }^{6}$ The Nile riparian states are; Burundi, the Democratic Republic of the Congo, Egypt, Sudan, Ethiopia, Kenya, South Sudan, Rwanda, Tanzania, Uganda and Eritrea, available at http://www.nilebasin.org/ (Accessed 23/12/2015).

${ }^{7}$ International Crisis Group (2006), Sudan Comprehensive Peace Agreement; the Long Road Ahead, Africa Report, No 106, Nairobi, Kenya, 2006(a), p.10.

${ }^{8}$ It shall be noted that South Sudan has entered international life at a time of uncertainty for the Nile. The agreement and utilization of the Nile River is a fragmented legal regime without an all-inclusive arrangement.

${ }^{9}$ Brenthurst Foundation (2010), Everything at Zero, Beyond the Referendum - Drivers and Choices for Development in Southern Sudan, E Oppenheimer \& Son Publishing Ltd, Marshalltown, South Africa, 2010, PP.18 Online, Available HTTP,

$<$ www.thebrenthurstfoundation.org,> (Accessed: 31/10/2010).

${ }^{10}$ As the fledging new nation looks to the Nile as an indispensable natural resource in its quest to achieve sustainable development, it will inevitably needs to consult with all its co-riparian on waterworks that it plans to construct on the water course. 
the studies have rarely focused on the impact of succession on trans-boundary water obligations, and more specifically in relation to the birth of South Sudan. For example, a study carried out on state succession to territorial obligations in the case of South Sudan has examined the theories of state succession and it reached at a conclusion that South Sudan is under an international obligation to honour the Nile Water agreements signed between Sudan and Egypt. ${ }^{11}$ However, the study rushes into a conclusion. Moreover, research made on recent changes on the Nile water and its Implication on South Sudan fails to take into account the recent development and current position of South Sudan. ${ }^{12}$ In-depth study and different scenarios have not yet been conducted especially with regard to its implication on the current fragmented legal regime governing the Nile River and its implication to Ethiopia.

The issues in relation to Nile agreements include (a) whether South Sudan is under international legal obligations to respect and honour the 1929 and 1959 Nile agreements made by Sudan with Egypt; ${ }^{13}$ (b) the conditions that may obligate South Sudan to fulfil its presumed international law obligation under the 1929 and 1959 Nile agreements; (c) the conditions that may relieve South Sudan from honouring its presumed obligation.; and (d) the laws or conventions of international law governing state succession that apply to a new successor state and more specifically to South Sudan.

The first section highlights the background of the study. Section 2 surveys the legal regime and the institutional framework that govern the utilization of the Nile river with particular emphasis to the 1929 and 1959 Agreements that were concluded between Sudan and Egypt. The third section focuses on the law of state succession specifically in light of the 1978 Vienna Convention on Succession of States in Respect of Treaties. ${ }^{14}$ Sections 4 and 5 deal with the succession to international trans-boundary waters agreements and succession of South Sudan to the 1929 and 1959 Nile Agreements respectively. Sections 6 and

${ }^{11}$ Mohammed Helal (2013), "Inheriting International rivers; State Succession to Territorial Obligations, South Sudan and the 1959 Nile Water Agreements", Emory International Law Review, 2013, p. 947.

${ }^{12}$ Nadia Sanchez and Yoyeeta Gupta(2011), "Recent Changes in the Nile Region may Create an Opportunity for a more equitable Sharing of the Nile River Water", Netherlands International Law Review: 363-385, 2011, p. 374.

${ }^{13}$ Prior to the independence of South Sudan, a number of International treaties and Basinwide cooperative arrangements regulated the use of the Nile waters by South Sudan. The most prominent of those is the Nile water Agreements concluded between Egypt and Sudan in 1929 and 1959. See Generally, R. O. Collins (1994), History, Hydro politics and the Nile: Nile Control: Myth or Reality? (in P. P. Howell and J.A Allan eds., 1994, The Nile. Sharing a Scarce Resource, 109, 110.

14 This part examines the 1978 Vienna Convention on States Succession in respect of Treaties, which is the principal international instrument. 
7 respectively analyse the implication of South Sudan's secession on 1929 and 1959 Agreements and future potential implications to Ethiopia.

\section{Brief Remarks on State Succession}

State succession refers to the actual substitution of a state by another with regard to sovereignty over a given jurisdiction in accordance with international law. ${ }^{15}$ It consists of any change of sovereignty over a given territory whose effect is recognized in international law. State succession includes both "succession in fact" and "succession in law" ${ }^{16}$ Succession in fact refers to the "factual situation in which, through some political evolution, a territory that previously was placed under the sovereignty of one state comes to fall under that of another state i.e. to the transfer of territory from one state to another". ${ }^{17}$ Succession in law refers to the "succession of the new sovereign to legal rights and obligations of the old sovereign, or more generally, to pre-existing legal situations". ${ }^{18} \mathrm{We}$ are here concerned with the succession of the obligations of the previous sovereign to its territorial successor.

Whenever there is a change of sovereignty in a given territory of a state (for example, when a part or parts of a given territory of a state separate from its parent state and become new independent state), many international legal issues relating to state succession arise. ${ }^{19}$ Some of the contemporary international legal issues that may arise with respect to state succession are related to the Nile agreements between Sudan and Egypt vis-à-vis the new state of South Sudan. ${ }^{20}$

The absence of accord governing South Sudan's utilization of the Nile increases different layers of multifaceted problems regarding the legal and institutional administration of the Nile basin. ${ }^{21}$ Nile is the largest river basin in the world without comprehensive agreement binding all riparian parties. ${ }^{22}$

15 Tim Hiller (1998), Source Book on Public International Law, 2rd ed., Demon Ford University, Leicester and Cavendish publishing Limited, Sydney, Australia, 1998, p.189.

${ }^{16}$ Ibid.

${ }^{17}$ Ibid.

18 Ibid.

${ }^{19}$ See Article 2 of the Vienna Convention on Succession of States in Respect of Treaties 1978 (Herein after cited as 1978 Vienna Convention and Vienna Convention on Succession of States in Respect of State Property, Archives and Debts 1983 (hereinafter cited as the 1983 Vienna Convention).

20 Charles L. Katz (2013), "Another Cup at the Niles Crowded Spigot: South Sudan and its Nile Water Rights"; Georgetown Journal of International Law, Vol. 44 1249-1279, p. 1252 .

21 Ibid.

${ }^{22}$ Dereje Zeleke Mekonnen (2010), "The Nile Basin Cooperative Framework Agreement Negotiations and the Adoption of a 'Water Security Paradigm' Flight into Obscurity or a logical Cul-De-Sac?”, 21 Eur. J. Int't L. 412, 440 (2010). 
Sudan and Egypt remain bound by the terms of the controversial 1929 and 1959 agreements for the full utilization of the Nile waters dividing the Nile between the two parties. It is under this setting that a newly independent South Sudan has yet to articulate its intentions which involve the international law issues ${ }^{23}$ highlighted in the following sections.

\section{The Nile Water Agreements}

The treaties and legal instruments regulating the use of Nile waters may be divided into three categories. ${ }^{24}$ These are:-

(i) Treaties between the United Kingdom and the powers in control of the upper reaches of the Nile basin around the beginning of the 20th Century ${ }^{25}$

23 Agreement for the full Utilization of the Nile Waters, Sudan-Egypt, Nov.8, 1959, 453 U.N.T.S 51, available at:

http:// internationalwaterlaw.org/documents/regionaldocs/uar_sudan.html (herein after cited as 1959 Nile Water Agreement).

${ }^{24}$ Arthur Okoth-Owiro (2004), State Succession and International Treaty Commitments: A Case Study of the Nile Water Treaties, Published by Konrad Adenauer Foundation and Law and Policy Research Foundation, Nairobi, Kenya, 2004,PP.21, Available at:

$<$ http://www.kas.de > (Accessed: 31/12/2014)

${ }^{25}$ The first of these agreements was concluded between Great Britain and Italy on April 15, 1891. See Carol Christina Carroll, Past and Future Legal Framework of the Nile River Baisn, 12 GEU, INT'N ENVTL.L. REV 276 (1999). This agreement was followed by a series of agreements between the United Kingdom and the upper Nile riparians. See Protocol Between the Governments of Great Britain and Italy for the Demarcation of their Respective Spheres of Influence in Eastern Africa, Apr. 15, 1891, 2 CONSOL. T.S. 434; see also Office of Legal Affairs, Legislative Texts and Treaty Provisions Concerning the Utilization of International Rivers for other Purposes than Navigation, at 127, U.N. Doc. ST/LEG/SER.B/12, U.N. Sales No. 63.V.4 (1963) at 115-27. The first of these agreements was signed with Ethiopia in Addis Ababa on May 15, 1902 (Ibid). Next, Great Britain concluded an agreement on May 9, 1906, with the Government of the Independent State of the Congo which undertook not to construct any waterworks on the Semiliki or Isango Rivers that would diminish the flow of water into Lake Albert. Agreement Between Great Britain and the Independent State of the Congo, Modifying the Agreement Signed at Brussels, 12th May, 1894, Gr. Brit.-Congo., May 9, 1906, 4 Consol. T.S. 2920. The treaty is also reproduced in Office of Legal Affairs, cited above in this note, at 99. Also in 1906, Great Britain, France, and Italy issued a tripartite declaration in which the three Powers pledged to protect " $[t]$ he interests of Great Britain and Egypt in the Nile Basin, more especially as regards the regulation of the waters of that river and its tributaries." C.O. Okidi, Review of Treaties on Consumptive Utilization of Waters of Lake Victoria and Nile Drainage System, 22 NAT. RESOURCES J. 161, 169 (1982). Then, during the period of June-December 1925, Italy, acting on behalf of Eritrea, and Great Britain, acting on behalf of the Sudan, exchanged notes to determine the amount of water that would be diverted from the River Gash for irrigation purposes in Eritrea. see also 
(ii) The 1929 Nile Waters Agreement;

(iii) Post-colonial treaties and other legal instruments (The 1959 Nile Waters Agreement).

The 1929 agreement was signed between Egypt and Great Britain on behalf of Sudan and other British colonies $^{26}$ in the basin (Uganda, Kenya, and Tanzania). ${ }^{27}$ The 1929 Treaty did not allow upper riparians to alter the Niles flow without obtaining consent first from the U.K. ${ }^{28}$ The agreement is "essentially directed towards the regulation of irrigation arrangements on the Nile basin." ${ }^{29}$ The Agreement included specific volumetric water allocations 48 billion m3 (Bm3)/year (yr) to Egypt and $4 \mathrm{Bm} 3 / \mathrm{yr}$ to Sudan - and helped to institutionalize the belief that Egypt and Sudan had 'natural and historic rights' to the Nile water. ${ }^{30}$ The 1929 agreement grants representatives of the Egyptian Irrigation Service in Sudan the liberty to cooperate with the Resident Engineer at Sennar Dam to monitor discharges. ${ }^{31}$ The parties agreed that with the exception of prior consent of the Egyptian Government:

no irrigation or power works or measures are to be constructed or taken on the River Nile and its branches, or on the lakes from which it flows, as far as all these are in the Sudan or in countries under British administration, which would, in such manner as to entail any prejudice to the interests of Egypt, either reduce the quantity of water arriving in Egypt, or modify the date of its arrival, or lower its level." ${ }^{\text {32 }}$

The second Nile Water Agreement commonly called the 1959 Agreement is aimed at the full Utilization of the Nile Waters. ${ }^{33}$ After the Independence of

Office of Legal Affairs, cited above in this note, at 127, U.N. Doc. ST/LEG/SER.B/12, U.N. Sales No. 63.V.4 (1963) at 12831.

26 The 1929 Treaty is remarkably one-sided, demonstrating, the British desire to appease Egypt in order to secure the shortest sea-route to British-controlled India via the Suez and Red Sea ports. See Arun P. Elhance, Hydropolitics in the Third World 69 (1999).

${ }^{27}$ David. S (2010), Nile Basin Relations: Egypt, Sudan and Ethiopia, George Washington University Press, Washington DC, USA, 2010, p.6, Available at:

$<$ http://www.mailto:elliott.org, $>$ (Accessed: 03/04/2015)

28 Joseph W. Dellapenna (1994), Treaties as Instruments for managing Internationallyshared water resource: restricted sovereignty v. community of property, 26 CASE W.RES. J. INT'L. L. 27, 48 (1994).

29 Jacob Granit (2010), the Nile Basin and the Southern Sudan Referendum, Regional Water Intelligence Publishing enterprise, Stockholm, Sweden, December, 2010, p. 41.

${ }^{30}$ Ibid.

${ }^{31}$ David. S, supra note 27, p. 6.

${ }^{32}$ Ibid.

33 Ana Elisa Cascão (2009), Changing Power Relations in the Nile River Basin: Unilateralism vs. Cooperation?, King's College of London Press, United Kingdom, 2009, p. 2, Available at: $<$ http://www.water-alternatives.org $>$. (Accessed: 10/11/2014). 
Sudan in 1956, Egypt's plans to build the High Aswan Dam and the need to renegotiate existing water allocations ${ }^{34}$ under the 1959 Agreement prompted the two countries to come up with new volumetric water allocations $-55.5 \mathrm{Bm} 3 / \mathrm{yr}$ to Egypt and $18.5 \mathrm{Bm} 3 / \mathrm{yr}$ to Sudan under a new agreement. ${ }^{35}$ The two parties agreed that Egypt constructs the Sudd-el-Aali and Sudan shall construct "the Roseires Dam on the Blue Nile and any other works which the Republic of Sudan considers essential for the utilization of its share, and including projects for the increase of the River yield." 36

The agreement between Egypt and Sudan further provides that the two parties agree on a unified view ahead of any negotiations with any other Nile riparian States and concerning Nile waters, if such negotiations result in an agreement to construct works on the river outside Egyptian and Sudanese territory. ${ }^{37}$ Egypt and Sudan also agreed to adopt a unified view in case other riparian States claim a share in the Nile waters; and if such claim results in the allocation of water to another Nile riparian State, ${ }^{38}$ the allocated amount would be deducted in equal parts from the shares of Egypt and Sudan. ${ }^{39}$ The 1959 Agreement also calls for the establishment of a Technical Commission for knowledge sharing purposes, and, in the event of a decrease in the Niles yield, this Technical Commission is entitled to determine the new water allotments. ${ }^{40}$

The 1959 Agreement lacks a severability clause - a treaty clause which states that the breach or the voiding of one part of the agreement does not result in the voiding of the entire agreement, thereby rendering renegotiation particularly difficult. ${ }^{41}$ Most relevant to the case of South Sudan is the complete absence in the 1959 Nile Waters Agreement of any provision relating to state succession, generally referred to as a "devolution provision." 42

A reference to the 1929 Agreement is made in the preamble of the 1959 Agreement between Sudan and Egypt, and this has been interpreted by some as

34 The official reason as stated in the preamble to the 1959 Nile Water Agreement itself was that "the Nile Waters Agreement concluded in 1929 provided only for the partial use of the Nile Waters and did not extend to include a complete control of the Rivers waters." See 1959 Nile Water Agreement.

${ }^{35}$ Ibid.

${ }^{36}$ Ibid.

${ }^{37}$ Jacob Granit, supra note 29, p.26.

${ }^{38}$ The 1959 Nile Water Agreement specifies the method of accession to the treaty. Article 7 declares that "this Agreement shall come into force after its sanction by the two contracting parties, provided that either party shall notify the other party of the date of its sanction, through the diplomatic channels."

${ }^{39}$ See 1959 Nile Water Agreement Art. 2(4).

${ }^{40}$ See 1959 Nile Water Agreement Art. 4(1)e.

${ }^{41}$ Ibid.

42 Ibid. 
evidence that Sudan has in fact not renounced to the continued binding effect of the 1929 Agreement. $^{43}$ As a result, the 1959 Agreement is not per se rejection and replacement of the 1929 treaty, ${ }^{44}$ although Sudan could have attempted to annul the 1929 treaty through rebus sic stantibus. ${ }^{45}$

The 1959 Agreement has reinforced down-streamer claims of 'natural and historic rights' to the Nile waters, and became the 'redline' demarcated by Sudan and Egypt for future negotiations in the basin. ${ }^{46}$ The upstream riparian states were not included in the Agreement, and have continuously criticized its bilateral nature. ${ }^{47}$ The 1959 Agreement represents the backbone of the hydro political dilemma in the Nile basin. Downstream riparian states want to maintain it while upstream riparian states want to replace it with a multilateral agreement based on equitable sharing. ${ }^{48}$

\section{State Succession under International Law in Respect to Treaties}

State Succession usually attracts remarks to the effect that it is 'undeveloped', 'confused', 'lacking in precision'. It is apparent that State succession is an issue that arises at transitional moments in international relations under distinctive circumstances. In the last century, for example, there were several discrete eras in which state succession became an issue: the post-war reconstruction of 1918 and 1945, the period of decolonization during the late 1950s up to late $1960 \mathrm{~s}$

43 Arthur Okoth-Owiro, supra note 24, p.20.

44 See 1959 Nile Water Agreements, Yimer Fisseha, State Succession and the Legal Status of International Rivers, in The Legal Regime of International Rivers and Laws 177,187 (in Ralph Zacklin and Lucius Caflisch eds., 1981). Though the 1959 Agreement effectually replaced 1929 Treaty, provisions in the 1959 Treaty that are not replaced explicitly repudiated remain valid. See Christina M. Carroll, "Past and Future Legal Framework of the Nile River Basin", 12 Geo. INT'T ENVTL.L.REW.269, 280 (1999).

${ }^{45}$ Rebus sic stantibus is Latin for "matters still standing." This principle of international law holds that all agreements are only binding as long as there are no fundamentally changed circumstances. Blacks Law Dictionary, 1381 ( $9^{\text {th }}$ Ed. 2009). Sudan's rebus sic stantibus claim is the change in status from colony to independent nation. Yimer Fisseha, supra note 44, p.186.

${ }^{46}$ Alan Nicol (2003), The Nile; Moving Beyond Cooperation, Printed by UNESCO, Division of Water Science, Paris, France, 2003, p.13 Available at: $<$ http//www.unesco.org/water/wwap/pccp > (Accessed: 11/02/2014).

${ }^{47}$ Ibid.

${ }^{48}$ Y. Arsano (2007), Ethiopia and the Nile - Dilemmas of National and Regional Hydro politics, Doctoral Thesis, ETH Zurich, 2007, p. 56. 
and more recently in the course of the 'restructuring' of the former Soviet bloc and the recent emergence of new states in the horn of Africa. ${ }^{49}$

State succession differs from government succession, and they involve different processes. Any change in the nature and identity of the governing authority does not affect the international legal personality of a state. ${ }^{50}$ In other words, international law distinguishes between a "change of State personality and change of the government of the State." "Wh "When governments change, "[t]here is a strong presumption that the State continues to exist, with its rights and obligations, despite revolutionary changes in government, or despite a period when there is no, or no effective, government", 52

International law has become increasingly significant in determining when and how to transfer legal responsibility from a predecessor state to a successor state. International dilemmas -including treaty obligations, debt responsibilities, and the allocation of assets- have been the subject-matter of significant debate and controversy. The International Law Commission has made significant progress in developing universal legal rules, yet a great deal of ambiguity remains. Thus the issue as to which laws or conventions are applicable to state succession deserves due attention.

There are three conventions which are directly related to succession of states under international law. These are the 1969 Vienna Convention on the law of treaties, the 1978 Vienna Convention on the succession of States in respect of Treaties, and the 1983 Vienna Convention on the Succession of States in respect of State Property, Archives and Debts. These three conventions can be used in resolving disputes relating to state succession between two or more states. ${ }^{53}$

The 1969 Vienna Convention on the Law of Treaties deals with how states enter into agreements. ${ }^{54}$ It lays the general procedures to be followed during formation and termination and further stipulates the effects of the treaties. It is a codification of customary international rules. ${ }^{55}$ The 1978 Vienna Convention deals with the succession of states in respect of treaties and is the most specific

${ }^{49}$ Matthew Craven (2002), The International Law of State Succession, International Law Forum du droit international 2: 2002-2005 @ 2000 Kluwer Law International, Netherlands, p. 202.

${ }^{50}$ James Crawford (2007), The Creation of States in International Law , 2d ed., p.34

51 Ibid.

52 Ibid.

53 Beato, Andrew M. (1994) "Newly Independent and Separating States Succession to Treaties; Considerations on the Hybrid Dependency of the Republic of the Former Soviet Union", American University Law Review 9, no.2 (1994): 527.

${ }^{54}$ Ibid.

${ }^{55}$ Tim Hiller, supra note 15, p. 189. 
international law dealing with state succession. ${ }^{56}$ The $1978^{57}$ Vienna Convention fills the gap regarding state succession and addresses the issues which the 1969 Vienna Convention on the law of treaties has failed to address. ${ }^{58}$

The close link between this convention and the 1969 Vienna Convention on the law of treaties has been stressed (in no less than three places) in the preamble of the 1978 Vienna Convention on the Succession of States in respect of Treaties. ${ }^{59}$ In the same preamble, it is stated that the provisions of this convention constitute codification and progressive development of international law. ${ }^{60}$ The 1978 Vienna Convention on the Succession of States in respect of Treaties substantially influences the practice of states and guides their interpretation in various unresolved succession matters. ${ }^{61}$

The 1983 Vienna Convention ${ }^{62}$ on the Succession of States in respect of State Property, Archives and Debts includes very specific provisions. It clearly states the provisions that should be used to resolve problems related to state property, archives and debts. ${ }^{63}$ But this convention does not form generally binding customary law because it has not attained the minimum number of signatory countries in order to bring the law in operation. ${ }^{64}$

Thus today the convention which is applicable to solve issues related with state succession is the 1978 Vienna Convention on the Succession of States in respect of Treaties. It has already been ratified by many states and is becoming customary international law because many states and the International Court of Justice solve problems of state succession based on the Convention. ${ }^{65}$ The following sections thus employ this Convention.

${ }^{56}$ Paul Reuter (1989), Introduction to the Law of Treaties, 1989, London; Brown Pinter Publishers, p. 23.

57 The 1978 Vienna Convention entered into force on 6 November 1997. The delayed entry into force gives rise to a number of questions including the reason why it took nearly twenty years for the Convention to obtain the necessary amount of ratification.

${ }^{58}$ Ibid.

${ }^{59}$ See the preamble of the 1978 Vienna Convention.

60 Ibid.

${ }^{61}$ Tim Hiller, supra note 15, p.189.

62 The Convention was adopted with 54 votes in favor (mainly socialist and developing states), with 11 votes against and 11 abstentions (western states). It has not entered into force, as it obtained only 6 accessions out of the fifteen required and six states have signed the conventions. See International Law association, Berlin Conference (2004), Aspects of the law of State Succession.

63 Ibid.

${ }^{64}$ Paul Reuter, supra note 56, p.33.

65 See case concerning the Gabcikovo- Nagymaros Projects (Hungary/Slovakia, Judgment of 25, September 1997 Paragraph 123, in which the court found that 1878 Vienna Convention to be declaratory of Customary international law. 


\section{Succession to International Transboundary Water Agreements}

There is much controversy (in the international legal discourse) on the concept of state succession. ${ }^{66}$ This is partially attributable to the uncertainty of state practice in relation to state succession and could be described on the grounds of a unique agreement and different set of rules distinct from "the category of state succession". ${ }^{67}$ Not many settled legal rules have emerged. ${ }^{68}$ Moreover, state practice with respect to succession is not coherent and is often determined not by legal but political considerations on a case by case basis. ${ }^{69}$ A number of academic theories have been proposed, the content of which remains subject to doctrinal debate. Such issues include the theory of universal continuity of treaties versus the theory of tabula rasa. ${ }^{70}$

In other words, it is not clear, from either writings on international law or the practice of states, how and to what extent a legal principle of state succession applies in the sense of the transmissibility of rights and obligations from one state to another. ${ }^{71}$ In fact, state succession does not entail an "automatic juridical substitution of the factual successor state in the complex sum of rights and obligations of the predecessor state." " Theoretically speaking, "where there is a separation or secession from an independent state which continues, in order to create a new state, the former continues as a state, albeit territorially reduced, with its international rights and obligations intact" ${ }^{73}$ With regard to the seceding territory, "the leading view appears to be that the newly created state will commence international life free from the treaty rights and obligations applicable to its former sovereign". ${ }^{74}$ This is, inter alia, because it is difficult to maintain (as a rule of general application) that non-signatory states to particular treaties are bound by them. ${ }^{75}$

${ }^{66}$ Mattew C. R. Craven (1998), The Problem of State Succession and the Identity of States Under International Law, European Journal of International Law 9 (1998), p.142.

67 Shaw, Malcolm N. (1991), International law, 3rd ed., Cambridge University Press, Cambridge, UK 1991, p. 253.

${ }^{68}$ Arthur Okoth-Owiro, supra note 24, p.27.

${ }^{69}$ Ethiopian International Institute for Peace and Development, the Historical Dispute over the Sharing of the Nile: Breaking the Deadlock and Charting a Way Forward, Addis Ababa, Ethiopia, June 3, 2010, p.7.

${ }^{70}$ Ibid.

${ }^{71}$ Paul Reuter, supra note 56, p.40.

${ }^{72}$ Ibid.

${ }^{73}$ Shaw Malcolm N., supra note 67, p. 253.

${ }^{74}$ Ibid.

75 Ibid. 
As a matter of general rule, a treaty cannot bind a non-party, and other parties to a treaty are not under legal obligation to accept a new comer party, as it were, by default. ${ }^{76}$ The rule of non-transmissibility applies both to "secession of newly independent states (that is, to cases of decolonization) and to other appearances of new states by the union or dissolution of states" ${ }^{77}$ To the general rule of non-continuity (the "clean state" doctrine) there are some exceptions. ${ }^{78}$ The clear examples are: "law-making treaties or treaties evidencing rules of general international law and/or boundary treaties". ${ }^{79}$

As some authors like Arthur Okoth-Owiro noted, a third category of treaties, which they call 'dispositive', 'localized' or 'real', are exceptions to the grand rule of non-transmissibility ${ }^{80}$ Dispositive treaties, are "those which create 'real' rights and obligations i.e. rights and obligations in rem in territory and immune to the change of sovereignty and rem with the land like the easement of English Common law or the servitudes of Roman law" ${ }^{81}$ Examples of such treaties include "river treaties, boundary treaties and treaties of peace and neutrality" ${ }^{82}$

Legally speaking, an international instrument governing succession into legal rights and obligations is the Vienna Convention on Succession of States in respect of Treaties, which was adopted on 23 August 1978 and entered into force in $1996{ }^{83}$ Article 2(1)(f) of the Convention defines successor state as the territory "which immediately before the date of the succession of states was a dependent territory for the international relations of which the predecessor state was responsible." Article 16 laid down the general rule that such states were not bound to maintain in force or to become a party to any treaty by reason only of the fact that the treaty had been in force regarding the territory in question at the date of succession. This approach was deemed to build upon the "traditional 'clean slate' principle applying to new states created out of existing states". ${ }^{84}$

\footnotetext{
${ }^{76}$ See Vienna Convention on the Law of Treaties Art. 34.

${ }^{77}$ Arthur Okoth-Owiro, supra note 24, p.30.

${ }^{78}$ Ibid.

${ }^{79}$ Ibid.

${ }^{80}$ Ibid.

${ }^{81}$ Ibid.

${ }^{82}$ Ibid.

${ }^{83}$ Some Nile riparian States have signed (Sudan) and ratified (Egypt and Ethiopia) this Convention.

${ }^{84}$ The proponents of the tabula rasa, or clean-slate doctrine of state succession argue that upon state succession the predecessor states personality and its identity completely disappear. The entirely new international sovereignty personality appears in its stead with no legal connection or derivation between the predecessors and successor entities.

See Daniel C. Turact, International Law and the New States of Africa, by Yilma Mekonnen, 8 Maryland journal of International Law, 303 (1984) available at $<$ http://digitalcommons.lw.Umaryland.edu/mjii/vol8/issue 217>.
} 
A sharp comparison exists between legal regimes of an international agreement on non-transferable rights and obligations in all cases of state succession except the 'clean slate' principle for decolonized nations as reaffirmed and validated by the Vienna Conventions and state practice. ${ }^{85}$ The 1978 Vienna Convention contains some customary international law rules on rights and obligations relating to the territory, e.g. those establishing boundaries or boundary regimes are not affected and, in effect, binding on successor states. ${ }^{86}$ More specifically Article 11 states that "a succession of states does not as such affect a boundary established by a treaty and/or obligations and rights established by a treaty and relating to the regime of a boundary" ${ }^{87}$

The literature on grounds of justifying claims of the invalidity of the treaties or their termination has been mixed as far as state succession and the colonial 1929 and 1959 Nile water treaties are concerned. Whether, colonial water agreements bind all the basin states is a question of considerable controversy. To use comments from one of the external assessors of this article, "All states that have taken part in the conclusion of the 1929 and 1959 Agreements have taken parallel positions regarding the binding nature of the agreements by reference to international law."

On the one hand, State practice and intention of contracting parties to the 1929 and 1959 Nile water Agreements are inconsistent with claims of their validity or continued application of the agreements. For instance, Great Britain had adopted the attitude that "the 1929 and 1959 Nile water Agreements should be renegotiated, and (in 1959) the British government had issued a statement to this effect" ${ }^{88}$ Almost all of the Nile basin states have adopted a doctrine on state succession to treaties they had concluded with Britain and have refused to be bound by them. This policy is known as "the Nyerere Doctrine on state succession" which views colonial-era treaties to be non-binding if such decision is in line with state interests. ${ }^{89}$

Available evidence also shows that states in the Nile basin are taking unilateral decisions (or sub-basin approaches) in the utilization and development of the Nile water. Tanzania, for example, "began to build a pipeline in 2004 to supply drinking water to approximately 1 million inhabitants of its parched

${ }^{85}$ Wasihun Aserre, State Succession and International Loan Agreements with reference to Eritrea, Senior Essay, Unpublished, Addis Ababa University, Faculty of Law, 1996, p.62.

${ }^{86}$ See Vienna Convention on State Succession Art. 11.

${ }^{87}$ Ibid.

${ }^{88}$ See Guarreston, "The Nile River System", Proceedings of the American Society of International Law, 1960:143.

${ }^{89}$ See Makonnen, Y., 1984. The Nyerere Doctrine of state succession and the new state of East Africa. Arusha: East Africa Publications. 
communities in Kahama and Shinyanga." 90 Kenya's and other riparian neighbours' need of water for various developmental-related works coupled with the strong desire of termination of colonial agreements have created a conducive environment to use the Nile water in the Great Lakes region. ${ }^{91}$ And, upstream nations namely, Ethiopia, Tanzania, Rwanda, Uganda and Kenya have signed the Cooperative Framework Agreement, that is meant to replace the 1929 and 1959 Nile Water Agreements. ${ }^{92}$ Thus, state practice seems to go contrary to the claim of validity or continued application of the treaties. To use a comment from one of the external assessors of this article, "concerning intention, as gathered from the treaties themselves, the attitude of the British government and Egypt does not evidence intention for the treaties being binding in perpetuity." Moreover, the majority of writers on the subject-matter have arrived at the conclusion that these treaties are not binding, with the "only controversial cases appearing to be the case of the 1929 and the Owens Falls Agreement." 93

On the other hand, some Egyptian writers are of the opinion that the Nile water treaties are valid and binding on the successor states. ${ }^{94}$ They argue that Egypt maintains 'natural and historical rights' that are "vested rights resting upon a solid legal, basis furnished by the principle of prior appropriation as acknowledged in international law and applied by courts in international and quasi-international disputes". ${ }^{95}$ According to Egypt, the 1929 agreement has also devolved to former British colonies in East Africa including Sudan and is subject to the provisions of the Vienna Convention on the Law of Treaties, which the International Court of Justice considers as codifying pre-existing international customary law. ${ }^{96}$ Egypt argues that the convention allows termination and suspension of the existing treaties only under the treaty

${ }^{90}$ Aaron Tesfaye (2012) "Environmental security, regime building and international law in the Nile Basin", Canadian Journal of African Studies / Revue canadienne des études africaines, 46:2, 271-287, p.272.

${ }^{91}$ Ibid.

${ }^{92}$ Id., p. 280.

${ }^{93}$ See Emmanuel B. Kasimbazi (2010) The impact of colonial agreements on the regulation of the waters of the River Nile, Water International, 35:6, 718-732, P.723 DOI: $10.1080 / 02508060.2010 .533642$ and Exchange of notes constituting an agreement between the government of the United Kingdom of Great Britain and Northern Ireland and the government of Egypt regarding the construction of the Owen Falls Dam in Uganda. Cairo, 16 July 1952 and 5 January 1953. Available from:

<http://internationalwaterlaw.org/documents/regionaldocs/owen-fallsdam3.html:

[Accessed 15 August 2010]. This agreement was entered into between Egypt and the British administration on behalf of the Uganda protectorate with regard to the construction of the Owen Falls Dam.

${ }^{94}$ Fahmy, A. M., "The Legal Regime of the River, 1986".

${ }^{95}$ Emmanuel, supra note 93, p. 726.

${ }^{96}$ Ibid. 
provisions by consent of the parties or by a fundamental change of circumstances that are preconditions (which according to Egypt) have not yet occurred. ${ }^{97}$

The contribution of the International Court of Justice's jurisprudence to the consolidation and clarification of the legal regime of state succession has been very minimal. ${ }^{98}$ This is principally attributed to two major reasons. First, while state succession has been a subject-matter of investigation by the ICJ since 1945 , the number of ICJ cases pertaining to it has been relatively insignificant. Second, and more importantly, when issues of succession arise, the Court with "the exception of Gabčíkovo-Nagymaros case has avoided addressing them in a principled way" and it has rather opted "to decide the underlying issues on a case-by-case basis, be it for reasons of judicial expediency or due to a lack of consensus among the members of the bench". 99 The only ICJ decision that has direct relevance to the subject matter at hand is the Gabčíkovo-Nagymaros case.

Notwithstanding many disagreements pertaining to treaty succession, it has been agreed that treaty regimes that regulate the use of territory (for example by placing certain restrictions on its use) 'run with the land' and thus are not affected by state succession. Against this background, the ICJ, in its 1997 Judgment in Gabcíkovo-Nagymaros, confirmed the view already taken by the ILC when it drafted the provision. ${ }^{100}$ Moreover, and again in line with the International Law Commission's position, the ICJ found that "treaties concerning water rights or navigation on rivers are commonly regarded as candidates for inclusion in the category of territorial treaties."

The transmissibility of boundary-related treaties to a successor state is justified in 'functionalist terms: 'prudence' and the desire to avoid the 'chaos that would ensue' should boundary treaties be open to renegotiation". ${ }^{102}$ The aforementioned justification is in favour of maintaining rights and liabilities related to boundary-related treaties of pre and post succession. ${ }^{103}$ The continuity of boundary treaties is less controversial, but there is debate about the

${ }^{97}$ Ibid.

${ }^{98}$ Andreas Zimmermann (2013). The International Court of Justice and State Succession to Treaties: Avoiding Principled Answers to Questions of Principles, Oxford University Press, p. 54.

${ }^{99}$ Ibid.

${ }^{100}$ Id., p. 63.

${ }^{101}$ In the Commentary on its Draft Articles on Succession of States in respect of Treaties, the ILC had identified 'treaties of a territorial character' as being unaffected by succession of states.

${ }^{102}$ Fasil Amdesion (2009), "Scrutinizing the Scorpion Problematique: Arguments in Favor of the Continued Relevance of International Law and a Multidisciplinary Approach to Resolving the Nile Dispute", Texas International Journal, Vol. 44:1, Texas, USA, 2009, p. 29.

${ }_{103}$ Ibid. 
transmissibility of boundary-related treaties to the new successor state. ${ }^{104}$ More specifically, there is the need to examine whether treaties governing transboundary water resources fall within the boundary exception "instead of the more expansive category of treaties that are nullified at independence". 105

It has been argued that international agreements pertaining to the use of international rivers could fall in the category of exceptional treaties instantly binding successor states as they are considered by some as annexed to the territory. ${ }^{106}$ However, newly independent African States such as Tanzania have often refused to be bound by water agreements concluded by predecessor States. ${ }^{107}$ A clear demarcation should be drawn "between rights and obligations concerning international rivers that are of territorial character and those rights and obligations that concern the waters flowing in a river in their characteristics as a natural resource". ${ }^{108}$ Established navigation rights are equated with the right to pass through a state's territory taking "advantage of the specific surface texture of water;" they are naturally linked to the territory of a State and thus are not altered by succession. ${ }^{109}$ The presumed transmissibility of rights and obligations that relate to water use as a natural resource, such as "water supply to non-riparian population would constitute an ex ante restriction of sovereignty of the new state with respect to its right to dispose of natural resources on its territory". 110

A supporting argument is found in the works of the International Law Commission, which drafted the 1978 Vienna Convention on Succession of States in respect of Treaties, and had declared its support for the principle of permanent sovereignty over natural resources. The Commission had voted in favour of article 13 for it was convinced that States must have full sovereignty over their natural resources. ${ }^{111}$ Article 13 had the merit of treating the principle

${ }^{104}$ Ibid.

105 Ibid .

106 An ideal example might be drawn from the recent Gabcicovo-Nagymaros case in which a central point of dispute was whether the agreement to construct a series of dam along the Danube was essentially in the nature of a treaty establishing a territorial regime and therefore subject to automatic succession. The response of the court to the question was in the affirmative, see case concerning the Gabcikovo-Nagymaros Project ( HungarySlovakia), Judgment of 25 September 1997.

${ }^{107}$ Arthur Okoth-Owiro, supra note 24, p.30.

${ }_{108}$ Jacob Granit, supra note 29, p. 40.

109 Ibid.

${ }^{110}$ Green Cross International, National Sovereignty and International Watercourses, Green Cross International printing press, Hague, Switzerland, March 2000, p.8.

${ }^{111}$ United Nations, Conference on Succession of States in Respect of Treaties 15th Plenary Meeting, Extract from volume II of the Official Records of the United Nations Conference on Succession of States in Respect of Treaties (Summary records of the 
of permanent sovereignty over natural resources as an element of international law. The Convention confirms and validates "the natural principle of international law of the sovereignty of every people and every State over its natural wealth and resources". ${ }^{112}$ It is very important to understand the structure and content of articles 11,12, 13 and 14 of the 1978 Convention and must be viewed as part of an entire package.

The International Law Commission felt that the transmittable rights and obligations of reciprocal international agreements concerning the new successor nation was not, in principle, a manifestation and affirmation of international customary law. The exception can the will of the concerned states and the grand rule with respect of reciprocal international agreements so that the postindependence transfer of rights and obligations becomes an issue for the parties to settle through a mutual agreement, expressly or impliedly, between the newly emerged nation and the other contracting members which had agreed with the predecessor state. ${ }^{113}$ The International Law Commission notes that a reciprocal bilateral international agreement applicable for the area in question is deemed to be applicable for the successor state and for the remaining other state party where there is an expressed mutual agreement or if it can be inferred from the conduct of the concerned states as if they have so agreed. ${ }^{114}$

\section{Succession of South Sudan to the 1929 and 1959 Nile Water Agreements}

Some authors like Mohammed argue that South Sudan's status determination in light of rules of international law pertaining to state succession is vital for the determination of applicable treaty rules. They contend that South Sudan should not be deemed as a newly independent state for the purpose of the 1978 Vienna Convention. ${ }^{115}$ Some also argue that the independence of South Sudan is an act of devolution, which is bilateral and consensual, and a different set of rules shall be applicable. However, it is irrelevant for the purpose of state succession whether South Sudan is a newly independent state or a separating state for the purpose of the discussion at hand. ${ }^{116}$

plenary meetings and of the meetings of the Committee of the Whole), Vienna, Austria, 31 July-23 August 1978,

p. 5 Available HTTP, <www.untreaty.un.org/org/cod/avt/vcssrt/html,> (Accessed: 06/11/2014).

${ }_{112}$ See Article 13 of the 1978 Vienna Convention.

${ }^{113}$ Id., See Article 24.

114 Ibid.

${ }^{115}$ Mohammed Helal, supra note 11, p. 947.

116 Ibid. 
It is true that International law recognizes a special category of treaties that establish territorial obligations. It is also true that strong weight of state acts and judicial opinion assessments confirm that these territorial obligations remain unaltered by state succession. The 1959 Nile water Agreement regulates the use of trans-boundary waters by two riparian states. This involves "regulating the exploitation of resources flowing through the territories of these two states". 117

However, the above assertion fails to distinguish between obligations that are purely territorial in nature and obligations which seem territorial in nature that are inherently related with the sovereignty of states to utilize their natural resources. When the transmissibility of the 1929 and 1959 Nile Agreements to the new state of South Sudan is examined in light of the 1978 Vienna Convention on Succession of States in respect of Treaties, South Sudan has an internationally recognized right to dispose of natural resources on its territory based on the principle of clean slate doctrine or tabula rasa. The 1929 and 1959 Nile Agreements are about the use of water as a natural resource, and the 1978 Vienna Convention on Succession of States in respect of Treaties under Article 13 has declared its support for the principle of permanent sovereignty over natural resources which is equally applicable to the new state of South Sudan. As Fasil notes, "the 1929 and 1959 agreements do not deal with the contours of boundaries in any shape or form but with the concrete issue of allocating the waters of the Nile between riparian states". ${ }^{118}$ The 1929 and 1959 agreements governing trans-boundary water resources do not thus fall within the boundary exceptional clause. ${ }^{119}$

It is also argued that the 1959 Nile water agreement is territorial in nature as the International Court of Justice recognized article 12 of the 1978 Vienna Convention as a rule of International Customary law in the GabčíkovoNagymaros case stating that "treaties concerning water rights or navigation on rivers are commonly regarded as candidates for inclusion in the category of territorial treaties" (citation 86 Para. 123). ${ }^{120}$ The 1959 Agreement is similar with the Gabčíkovo-Nagymaros case in one major component: its purpose was to regulate the construction of water dam projects on specific parts of the Nile within the territory of Sudan and Egypt ${ }^{121}$ which are similar in nature to the

\footnotetext{
${ }^{117}$ Id., p. 964.

${ }^{118}$ Fasil Amdesion, supra note 102, p. 35.

119 Possible Egypt and Sudan recourse to the boundary exception or other negations of the tabula rasa doctrine are likely to be imperfect rebuttals at best, for Cairo and Khartoum have previously denounced treaties signed by the Great Britain on their behalf, "Id they no longer reflect their development needs." See Christina Carroll, "Past and Future Legal Framework of the Nile River Baisn", GEO. INT'L ENVTL. REV, 269, 279, (1999).

${ }^{120}$ Nadia Sanchez and Yoyeeta Gupta, supra note 12, p. 374.

${ }^{121}$ See 1959 Nile Water Agreements, Arts 2-3.
} 
system of locks on the Danube. ${ }^{122}$ However, the 1929 and 1959 agreements fix allocations and they rely "on the theory of limited territorial sovereignty as its legal doctrinal framework". ${ }^{123}$ Under the 1959 Nile Agreement, the two countries came up with volumetric water allocation-55 Bm3/yr to Egypt and $18.5 \mathrm{Bm} \mathrm{3/yr}$ to Sudan. It can be concluded that the agreement was primarily designed with the simple allocation and full control of the Nile water which cannot be regarded as a territorial treaty.

Moreover, the 1929 and 1959 agreements lack a state succession provision, and international law governing state succession in respect to treaties is limited to customary international law, which holds that the successor state must accept treaty obligations for them to remain binding. ${ }^{124}$ Therefore, the 1929 and 1959 Nile water agreements come under extensive list of treaties that can be nullified at any time. ${ }^{125}$ To put it differently, the new state of South Sudan can nullify the agreements if it wishes to do so according to Article 24 of 1978 Vienna Convention on Succession of States in respect of Treaties.

The Vienna Convention on Treaties (which entered into force in 1980) lacks any provision pertaining to the succession of states in respect to treaties. ${ }^{126}$ Rather, the Convention on Treaties considers South Sudan a third state, nonparty, in relation to the 1959 Nile Water Agreement ${ }^{127}$ and a third state must assent in writing to an international agreement in order to be bound by rights and obligations emanating from the treaty. ${ }^{128}$ The 1959 Nile Water Agreement does not bind South Sudan under the convention on treaties because South Sudan has never consented in writing. ${ }^{129}$ Though, Sudan ratified the Convention and Egypt acceded to it, ${ }^{130}$ as Charles pointed out, "a potential conflict between the Convention on Treaties and the Convention on State Succession on this matter is averted by Article 4 of the Convention on Treaties" which limits "the scope of the convention to treaties enacted after the Convention came into force in 1980. ${ }^{131}$ The Convention on Treaties, because of the non-retroactivity clause

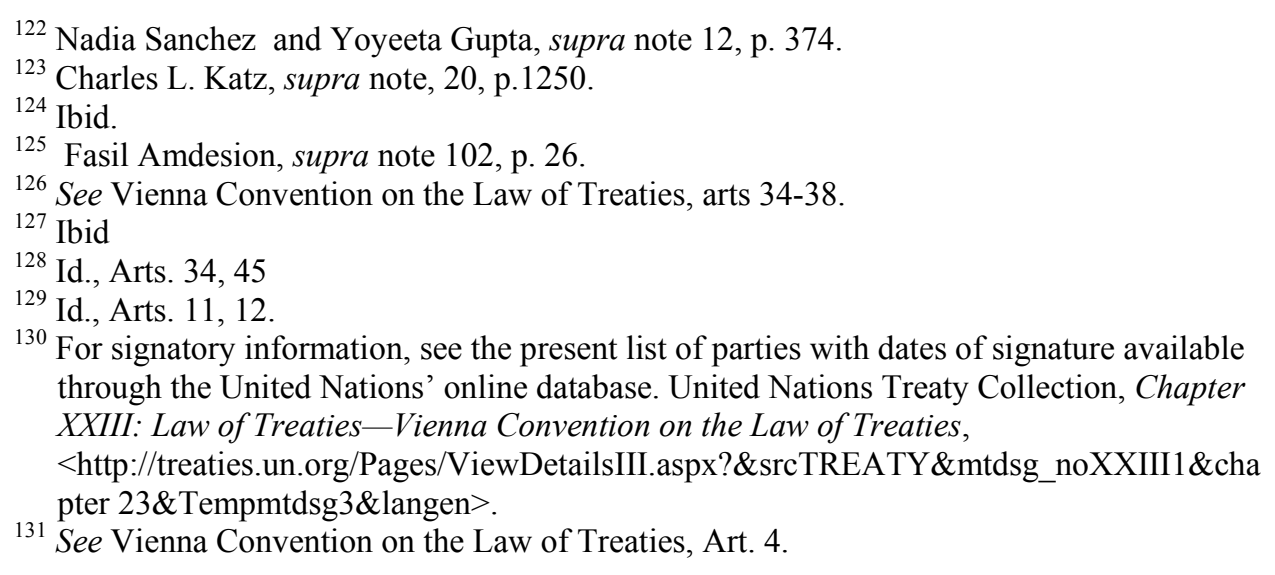


(Article 4), therefore, does not apply to South Sudan and the 1959 Nile Water Agreement.

While Egypt has signed and ratified the Convention on State Succession, Sudan has yet to endorse the agreement through ratification process, implying that this Convention currently lacks the power to bind both parties. ${ }^{132}$ Sudan was never a member party to the Convention on State Succession, and the 1959 Nile Water Agreement under the Convention on State Succession does not bind South Sudan. This author's argument is supported by the 1978 Vienna Convention. Article 35 of the Convention provides:

When, after separation of any part of the territory of a State, the Predecessor State continues to exist, any treaty which at the date of the succession of States was in force in respect of the Predecessor State continues in force in respect of its remaining territory unless:

(a) the States concerned otherwise agree;

(b) it is established that the treaty related only to the territory which has separated from the predecessor State; or

(c) it appears from the treaty or is otherwise established that the application of the treaty in respect of the Predecessor State would be incompatible with the object and purpose of the treaty or would radically change the conditions for its operation.

This provision of the Convention states that as a general rule, if a state continues to exist after separation of part of its territory, any treaty which at the date of the succession was in force in respect of the predecessor state continues to be in force in respect of its remaining territory. This means that the predecessor state territory will be bound by the treaty unless the exceptions enumerated under the same article apply. The first exception to the general rule applies when the concerned states agree otherwise. ${ }^{133}$

The second exception is when a treaty in force at the date of succession was made for the sole benefit of one of those territories which are now successor states and related only to the territory separated. Had this exception been applicable, Sudan could have declared that the 1929 and 1959 Nile agreements are no longer binding as the direct consequence of South Sudan succession and fundamental changes in the circumstances of the state concerned.

Article 62(2) provides an exception where fundamental change of circumstance may not be invoked as a ground for termination or withdrawing from a treaty. One major exception is if a treaty establishes a boundary whereby treaty cannot be terminated even if the grounds for the existence of fundamental

132 Ibid.

133 At the time of writing this Article, Sudan and Egypt have succeeded into the right of the 1929 and 1959 Agreements, See <http://www.dailynewsegpt.com/2014/00/21>. 
change of circumstances are present. The second exception is if the fundamental change is the result of a breach by the party invoking it either with regard to an obligation under the treaty or any other international obligation owed to any other party to the treaty. Examining the facts against the above exceptions, the 1929 and 1959 Nile Water Agreements are not treaties that establish boundary and are meant to ensure full hegemonic control over the Nile water resources. The principle of rebus sic stantibus (change of circumstances) cannot thus be waived with regard to the 1929 and 1959 Nile Water Agreements. The birth of South Sudan constitutes fundamental change of circumstance which is an event that can enable Sudan if it opts to set aside its obligations under the 1959 Nile water agreements. Thus, there is no room for the application of the exceptions and the option of termination of the Nile treaties remains open, not only to South Sudan, but to Sudan as well.

As a comment from one of the external assessors indicates, some writers contend that rebus sic stantibus causes immediate termination of a treaty in question, while others claim that it merely provides a state an option to terminate it. Article 45 of the Vienna Convention seems to adhere to the second approach, and it provides that a ground for invalidity, termination, withdrawal or suspension "may no longer be invoked by the state where, after becoming aware of the facts, it expressly agreed that the treaty is valid or remains in force or by reason of its conduct may be deemed to have acquiesced in the validity of the treaty or its continuance in force." In light of article 45 of the VCLT, Sudan has not (after the birth of South Sudan) taken a concrete measure to terminate the 1959 Nile water Agreement obviously for pragmatic purposes. Sudan has thus so far upheld the 1959 Nile Water Agreement thereby confirming similar positions with Egypt. ${ }^{134}$

\section{Legal Implications of South Sudan's Separation on the 1929 and 1959 Nile Water Agreements}

The South Sudan referendum conducted in January 2011 decided overwhelmingly for separation from Sudan. ${ }^{135}$ South Sudan will have to decide on how to proceed on succession with respect to the international Nile water agreements currently applicable in the territory; e.g. (a) apply universal continuity by unilateral declaration of succession, or (b) review Nile water treaty

${ }^{134}$ Egypt Nile Quota Too Low, Al Ahram Weekly, Jan 15, 2013, Sudan's Bashir Visits Egypt, Confirms ' Identical Positions on the Nile Water Disputes; Sudan Tribune, Sept. $17,2015$.

${ }^{135}$ See, South Sudan's Flag Raised at Independence Ceremony, BBC News (July, 2011), $<$ http:// www.bbc.co.uk/news/world.africa.14092375>. 
and declare subsequently whether to be bound or not. ${ }^{136}$ And, a possible third option is a pledge of neutrality on the utilization of the Nile Water Agreements. ${ }^{13}$

The 1929 and 1959 Nile bilateral agreements do not include any provision regarding State succession, ${ }^{138}$ and thus a unilateral declaration of succession by South Sudan need to be accepted by other contracting Parties. Response to a unilateral declaration of universal continuity of international Nile water treaties by South Sudan can apparently be welcomed by Sudan and Egypt and South Sudan's accession to these treaties can be effected by notification to the depository because accession is generally not contended by other contracting Parties.

The second option is review of the treaty. The objective of multilateral treaties is to unite as many States as possible. To this end, South Sudan, Sudan and Egypt on the occasion of the emergence of the new state of South Sudan can see an opportunity to renegotiate the 1929 and 1959 Nile bilateral agreement on a case-by-case basis. A possible third option is a pledge of neutrality on the utilization of the Nile Water Agreements.

The course of action pursued by South Sudan has impact on its relationship with the upper and lower riparians of the Nile. The state of volatility in the sharing of water resources can be thus adversely affect or facilitate Sudan's future development ambitions, depending on how the country will pursue its water policies in the volatile political environment. ${ }^{139}$

\section{South Sudan's Prospective Position on the Nile Agreements and its Implication to Ethiopia}

Legal separation of South Sudan and its possible future position on the Nile issue can either strengthen the one sided colonial treaty signed between Egypt and Sudan or can create a new era of unifying the entire basin members into a new inclusive legal regime governing the utilization and management of the Nile River. South Sudan's acceptance or rejection of the 1929 and 1959 Nile

${ }^{136}$ As of writing of this article, the Government of South Sudan has not announced its intention to undertake major water works. Also, it is unclear what the position of Government of South Sudan is regarding the existing legal framework of the Nile river.

${ }^{137}$ Roozenbeek, J., (2014): A New Stalemate: The Influence of South Sudan's Independence on the Nile Basin's Water Politics. Master thesis in Sustainable Development at Uppsala University, 2014, 15 ECTS, p.28.

${ }_{138}$ See the 1959 Nile Water Agreement Section 2.1.1.

139 Samson S. Wassara (2003), South Sudan in Volatility of Sharing the Nile Basin Resources, in Elke Grawert (eds.), Forging two Nations Insights on Sudan and South Sudan, Organization for Social Sciences in Easter and Southern Africa, 2013, p.239. 
water agreements could have positive or negative consequences on Ethiopia's long awaited quest for fair and reasonable utilization of the Nile River since the Nile River is a common and shared natural resource that connects the people of all basin members. There are three options for South Sudan on the issue of the 1929 and 1959 Nile Agreements. The first option is succession to the 1929 and 1959 Agreements, the second is refusing succession to the Agreements and third is remaining neutral.

Under the first scenario, one of the issues to be analyzed is what would be the future potential implication to Ethiopia and other riparian states? If South Sudan decides to succeed into rights and obligations of this agreement, this would be a clear signal of alignment with the downstream riparian states. ${ }^{140}$ Ethiopia as one of the upstream riparian states will have to deal with a threefront negotiation which could be a political obstacle to nullify and reduce the binding nature of the 1929 and 1959 Nile Agreements as the Nile remains without an all-inclusive legal regime to regulate its use. ${ }^{141}$

If the Sudan and Egypt agree to this succession, water allocations under the agreement would need to be renegotiated. It is unlikely that Egypt would accept a reduction of its allocated share ${ }^{142}$ in a renegotiation which involves Sudan, South Sudan and Egypt. Sudan and South Sudan would have also to negotiate regarding the current allocation to Egypt. ${ }^{143}$ Moreover, the fifth article of the 1959 Nile Agreement, which requires a unified position in negotiations concerning Nile waters with any other riparian State, would apply to South Sudan under this scenario. In other words, South Sudan must have a unified stand with Sudan and Egypt against Ethiopia and other upper riparian states. The requirement of a unified negotiation position would thus curtail South Sudan's freedom in engaging in various projects with its upstream neighbours.

Furthermore, the 1959 Agreement provides for the construction of water conservation schemes in South Sudan. ${ }^{144}$ This is an implicit reference to the Jonglei canal project, a project which is not very popular in the South. ${ }^{145}$ The

${ }^{140}$ Nadia Sanchez and Yoyeeta Gupta, supra note 12, p. 365.

141 South Sudan accession means that the three countries (Egypt, Sudan and South Sudan) would effectively participate as a unified block in any Nile-related negotiations without outside parties. See the 1959 Nile Agreement Art. 5(2).

142 Egypt Nile Quota Too Low, Al Ahram Weekly, Jan 15, 2013, Sudan's Bashir Visits Egypt, Confirms 'Identical Positions on the Nile Water Disputes; Sudan Tribune, Sept. 17, 2015.

143 While Egypt's share of 55 bcm should remain unaffected by the session of South Sudan, the later must enter into negotiations with Sudan to reapportion their respective shares, see Katz, supra note 20, p. 1266.

${ }^{144}$ Jacob Granit, supra note 29, p. 39.

${ }^{145}$ Ibid. 
Sudanese government would have been able to restart construction activities on the canal during the interim period, but the Southern Sudanese government has stated 'it's environmental, social and economic concerns with the project, and [has] expressed its unwillingness to cooperate on expanding the canal. ${ }^{146}$

Under the second scenario of refusing the succession to international Nile water treaties, South Sudan could follow the Nyerere Doctrine, i.e., reviewing earlier treaties regarding their binding effect. ${ }^{147}$ With respect to the 1929 Nile Water Agreement, it could claim further that it was concluded under colonial rule. ${ }^{148}$ In not accepting the binding force of the 1959 agreement, South Sudan would signal alignment with the upstream neighbours. ${ }^{149}$ Ethiopia as upstream riparian state will have to deal with a two front negotiation which could easily reduce the binding nature of the 1959 Nile Agreement and pressure Egypt and Sudan to renegotiate the 1959 Nile Agreement. And, South Sudan will be a potential ally for influencing the downstream countries in future water sharing arrangements.

South Sudan might further decide to sign and ratify the Cooperative Framework Agreement (CFA), a step that can most likely antagonize Sudan and Egypt if these countries continue to remain outside the Framework. Article 42 of the CFA states that it shall enter into force "on the sixtieth day following the date of the deposit of the sixth instrument of ratification or accession with the African Union". ${ }^{150}$ In order to change this requirement, the treaty text needs to be reopened for negotiation, which is unlikely. The treaty does not limit signature to the ten States listed. Article 40 states that it is "open to signature by all States in whose territory part of the Nile River Basin is situated". ${ }^{151}$

The CFA can provide South Sudan with greater flexibility for its current and future water needs, stronger ties with socio-cultural regional peers, and greater domestic sovereignty. ${ }^{152}$ The cost of the CFA would be lack of a 'guaranteed allotment ${ }^{153}$ to the dissatisfaction of Egypt which in return (to befriend riparian

146 See, Kiir, S., 2010: Interview of the President of South Sudan, Mr. Kiir Mayardit, by

Sudanile. Accessed: <www.sudanile.com/index.php?option=com>.

${ }^{147}$ Jacob Granit, supra note 27, p 39.

148 South Sudan Set to Sign New Nile Agreements, Aljazeera English, 20 June 2013, at $<$ http://www.aljazeera?news?africa?201306>.

149 See South Sudan admitted into EAC, daily Nations (March 2, 2016) at $<$ www.nations.co.ke/business/South-Sudan $>$.

${ }^{150}$ Nile Basin Initiative, "Agreement on the Nile River Basin Cooperative Framework opened for signature”, Available:

$<$ http://www.nilebasin.org/index.php?option=com_content\&task=view\&id=165\&Itemid=1> (Accessed: 15/01/2015).

151 Ibid.

${ }^{152}$ Charles L. Katz, supra note 20, p. 1279.

153 Ibid. 
states), can provide South Sudan with much needed resource to its most pressing economic and social services. A policy of equitable and reasonable utilization represents an ideal short-term solution for South Sudan in that it attempts to minimize any negative trade-offs while maximizing the positive benefits. ${ }^{154}$

The third scenario would mean a pledge of neutrality on the use of the Nile waters. This scenario can involve a unilateral decision-making process in the utilization and management of the Nile water without being part of any alternative legal regime advocated by Egypt and Sudan on the one hand and CFA signatories on the other hand. This option pleases the lower riparian states, i.e., Egypt and Sudan that have a strategic and vested interest in befriending South Sudan so as to be able to influence its foreign and regional policy.

Notwithstanding the above scenarios, it is also important to consider the interest of South Sudan in light of the upper and lower riparian state discussions. As South Sudan lies almost entirely in the White Nile catchment area, and has no hydrological or geographical dependence on the Blue Nile, it is equally a lower and an upper riparian state depending on the flow of the Nile River. It is a lower riparian state as compared to Ethiopia and an upper riparian state as compared to Sudan and Egypt. It will be hydrologically impossible to coordinate development projects without the consent of Ethiopia, if South Sudan prefers to join the old colonial water treaties. The 1959 water agreement reinforces "inequality by denying the upper riparian states rights to development programs", and South Sudan as an upper riparian state to Sudan and Egypt cannot be an exception. As a free state and an upper riparian state, South Sudan needs to play its diplomatic cards well without being handicapped by the provision of the 1959 Nile Water Agreement. ${ }^{155}$

After all, projects that could benefit South Sudan, such as hydropower were not articulated in the 1959 water agreement. As it can be clearly understood from the text of the agreements, a reference is made to the water development of 'Jongeli Canal Project' with the sole intention of benefiting the then Sudan and Egypt. ${ }^{156}$ In accordance with the 1959 Nile water agreements, the additional water yield of the project would be split between Egypt and Sudan upon completion. Moreover, the fact that the agreement was not concluded for the sole benefit of South Sudan can be clear when one examines the wording of the Nile development initiatives to increase water yields of the Nile. ${ }^{157}$ The 1959 Agreement thus empowers Egypt to begin construction projects within Sudan in order to increase the yields of the Nile. ${ }^{158}$

\footnotetext{
${ }^{154}$ Ibid.

${ }^{155}$ Samson S. Wassara, supra note 139, p. 239.

${ }^{156}$ See the 1959 Nile Agreement.

${ }^{157}$ Ibid.

${ }^{158}$ Ibid.
} 
It is thus in the best interest of South Sudan to join the Cooperative Framework Agreement (CFA), which is considered as a replacement of the 1959 Nile Agreement and advantageous to possible future development pursuits along the Nile. The government of South Sudan has already made "a declaration of intention to sign the agreement during the June 2013 annual Nile-Com Conference in Juba in 2013". ${ }^{159}$ South Sudan is already full member of the NBI and is expected to be signatory of the CFA, as a result of which the 1959 Agreement is increasingly becoming irrelevant in South Sudan.

\section{Conclusion}

Had there been an all-inclusive and agreeable legal regime governing the Nile Basin, South Sudan's succession of the colonial 1929 and 1959 Nile Water Agreements would have been irrelevant. However, that is not the case. The Nile remains governed by a fragmented legal regime. Some of the treaties comprising this regime are inherited from the colonial era and South Sudan has to deal with the subject matter as a new independent state within the context of state succession.

The major argument in this article is that the birth of South Sudan has created the question of state succession and that the 1929 and 1959 Nile agreements concluded between Sudan and Egypt do not bind the new state. I argue that the 1929 and 1959 agreements governing trans-boundary water resources of the Nile do not fall within the boundary of exceptional clause thereby enabling the new state of South Sudan to nullify the agreements at any time.

However, the aforementioned conclusion depends on the possible political choice of South Sudan, which could lead into three scenarios with different implication to Ethiopia and other riparian states of the Nile basin. The first scenario is acceding to the Nile water agreements to the satisfaction of Egypt and to the disappointment other Nile basin countries that have invalidated the agreements. The second scenario is rejection of the colonial Nile water treaties and having clear signal of alignment with the upstream riparian states including Ethiopia. A possible third scenario is a pledge of neutrality on the utilization of the Nile.

South Sudan's preferred choice among the three scenarios will demonstrate the political and economic aspects of international watercourse rights. Since the availability of water is vital for economic development of country, South Sudan's recourse to a particular scenario among the options is expected to be guided by the nation's economic and political goals as each scenario presents with its own blessings and curses.

159 Samson S. Wassara, supra note 139, p. 239. 